\title{
Evolutionary biology as a link between religion and knowledge
}

\author{
C W du Toit \\ Research Institute for Theology and Religion \\ Faculty of Theology and Religious Studies \\ University of South Africa
}

\begin{abstract}
It would appear that the epistemological tradition of the West is culminating in the present science-religion debate. The evolutionary model is being used increasingly in different disciplines as a guideline to understand humans and their action in the world. The struggle for explaining the action of God has shifted from the world of history and texts to the invisible level of quantum physics and molecular biology. It seems that levels of indeterminacy in quantum mechanics and autopoietic systems offer space to explain the action of God. On the human level integrity is sought by linking the highest level of consciousness and rationality to the very basic level of molecular and genetic structures. These issues are dealt with and specific attention is given to autopoietic systems and the biological roots of rationality.
\end{abstract}

\section{INTRODUCTION: THE RESURFACING OF THE EVOLU- TIONARY MODEL}

It seems as if the epistemological tradition of the West is culminating in the present science-religion debate. Many epistemological positions are being reconsidered or revamped in the light of challenges posed from the side of the natural sciences. Most epistemological theories like foundationalism, realism, critical realism, postfoundationalism, postmodernism all claim to occupy the best position from which to deal with the science-religion relationship. The resurgence of natural theology, naturalism, evolutionary biology also contribute significantly to the debate. Gregersen and Van Huyssteen (1998) present the following six models as being prominent in the debate: 
- $\quad$ postfoundationalism (Van Huyssteen);

- $\quad$ critical realism (Van Kooten Niekek);

- $\quad$ naturalism (Drees);

- $\quad$ pragmatism (Hermann);

- complementarism (Watts); and

- $\quad$ contextual coherentism (Gregersen).

Although these models can be distinguished from one another, they overlap in many areas. One would, however, be mistaken if one considered the debate to be restricted to philosophical and epistemological positions. The debate goes much further: important religious issues like the providence of God, God's role in the continuing of creation, the mind-body dualism, the moulding of present day world-view, ethics and anthropology are all included.

The evolution model is being used increasingly in different disciplines as a guideline to understand humans and their actions in the world. With developments in quantum mechanics and molecular biology the focus of theological attention has moved from the macro to the micro level. The struggle for explaining the action of God has shifted below the visible world to the level of quantum physics and molecular biology. It seems that biology has become a kind of model science replacing the previous role of physics in generating a world view (Gregersen 1999: 135). The influence of evolutionary biology comes to the fore in evolutionary psychology and evolutionary ethics as well as in the influence it exerts on language theory, and in society as a social system. In evolutionary psychology the biological roots of behaviour are researched in order to understand human sexuality, consciousness, fear, and human preferences. Evolutionary ethics studies human genetic composition to explain social and cultural patterns and life styles. On a theological level theologians have to rethink the nature of their rationality and theological models like the doctrine of creation, God's providence and action in the world, eschatology, the problem of evil, human sexuality and ethics. The reformulation of models may be sought for various reasons, such as the wish to defend the consistency of scientific knowledge and for the credibility of religious convictions, or the desire to formulate an approximately adequate view of reality, or the wish to develop images and 
metaphors which communicate the religious message to persons whose world-view has been shaped by science (Drees 1996:198). Theologians seem to be compelled to relate to the ideas of evolutionary biology because of the importance of the claims that are made and because of the ostensible influence it exerts in formulating present day world-views. The natural selection paradigm must be metaphorised, according to Van Huyssteen (1998:141), to include some of our most crucial epistemic activities such as learning, science and religion.

Although the evolutionary model has been around since Darwin and neo-Darwinism, it has never been applied as it is now, namely to the fields of religion, psychology and culture. In the past, modernist and foundationalist sentiments have prevented the application of an open-ended model that favours evolutionary multiplicity. Only within the postmodern world are these options taken seriously.

Van Huyssteen (1998:160-161) hopes to overcome the present uncomfortable science-religion relationship by posing evolution by natural selection as the mutual ground for all forms of rationality. He believes that this may avert an alleged idea that natural science is a superior form of rationality and that it may prevent religious rationality from retreating into an esoteric safe haven. He does not see science and religion as two distinct rationalities, but as both linked to the same biological roots and situated within the context of living, developing and changing tradition. Willem Drees (1996:3) however, feels that to claim that science and religion are separate cognitive enterprises of equal status is too easy a way out. The claim that the theological enterprise is a rational one does not necessarily ward off all problems and the science-religion dialogue cannot simply be resolved by posing evolution by natural selection as the common background for both disciplines. It is also unclear how this may resolve the modernist distinction between science and religion as separate rationalities. Is the idea of our common biological roots really different from the general idea of a common humanity, common language and a common culture that we share, and if so, how precisely does it help us to obviate obstacles in the debate? One needs to focus on exactly what these common biological roots are, and how evolutionary epistemology really influences rationality, promotes interdisciplinarity and links science and religion as 
separate disciplines. This paper seeks to ponder on this challenge by focussing on the idea of autopoietic systems.

\section{IMPLICATIONS FOR THE DIALOGUE BETWEEN THEO- LOGY AND THE NATURAL SCIENCES}

Although religious knowledge presupposes faith and faith-related experiences and although scientific knowledge is based on empirical observation, the cognitive rules determining these two disciplines are allegedly the same. But it must be recognised that science and religion approach their subject matter differently. They ask different questions and answer them on the basis of their distinctive methodologies, yet yielding answers which are mutually harmonious and enriching. A "two-language" approach to the matter, in which both science and religion offer linguistically distinct, yet complementary approaches to reality, has been offered by Gilkey (McGrath 1998:186). In the light of this approach one may expect a theological response on the findings of evolutionary biology. The theological response should not, however, be limited to apologetic-sounding arguments which indicate the place and action of God in evolutionary biology; it should also, for example, try to spell out what the implications of evolutionary epistemology and evolutionary ethics are for religion. For, example, how do the evolutionary metaphors of struggle, survival and power impinge on religion? From a postmodernist side Foucault and many others in the Nietzschean tradition have referred to the important role that power plays in human interaction. Christianity, in spite of its ostensible emphasis on altruistic love and the weakness of the cross has strong implicit power-seeking features. An acknowledgment of the role which power plays in humans must be re-evaluated in the light of evolutionary biology. In the words of Nietzsche (quoted by Thiselton 1995:16-17), Christianity has sided with everything that has been botched, and everything that is weak and low; it made an ideal out of antagonism against all the preserving instincts of strong life.

Both science and religion exert an important influence on human self-understanding and world-view formation. Faith wants to understand fides quaerens intelluctum). Religious arguments, like those of science, must be logical, consistent and congruent. We know that both religious and scientific knowledge are influenced by 
tradition and culture, custom and fashion and that both may fall prey to one-sided approaches like foundationalism, reductionism, absolutism or relativism. These commonalities already provide a mutual basis for dialogue.

Four possible stances in the science-religion debate can be identified, namely dialogue, conflict, integration and independence. The involvement of theologians in the debate must be seen in the light of the struggle to come to grips with the challenges posed by natural science and specifically by evolutionary biology. What cannot be doubted is that the science-religion debate depends on some form of consensus being reached in the area of cognition and human self-understanding so as to define the place and importance of both disciplines.

In the last few decades Christian apologetics has shifted from focussing on doctrinal issues to the science-religion debate. Fascinating developments in the fields of physics, molecular biology and new cosmology have made it possible to understand the creation process without the God-hypothesis. In this sense science has become the religion of our age (see Appleyard 1992:83, 228ff). In reaction to this development, theologians have reverted, amongst others, to biblical hermeneutics, language theories and useful scientific models to put their case. Models like that of quantum physics, autopoiesis and evolutionary epistemology present an opening for theologians to introduce God's action in these processes. The anthropic theory, autopoietic systems and evolutionary epistemology each allow - because of indeterminate elements - space for the action of God. The apologetic motive of theologians may, however, colour their evaluation and selection of scientific findings.

Theologians seem to be on an apologetic foot in the science-religion debate, since theology is seemingly in the least favourable position in the debate. The agenda is to a large extent determined by the natural sciences. It is theologians who have to align biblical ideas with contemporary science models rather than that scientists have to accommodate religious ideas. Instead of God filling the gaps in scientific theories, the opposite seems to be the case where the scientific models (especially those that allow indeterminacy, like quantum theory and autopoiesis) offer a space for explaining God's action in the world. However, one would not like the theological engagement in the debate to be reverted to a non-interactionist stance where an exclusivist position of God 
as the "Ganz Andere" inhibits any dialogue. The contribution of theologians seems to fit well into a so-called theology 2 level (see Gregersen's "God: The creator of creativity" in this volume) where broader philosophical, symbolic and metaphoric reflection takes place. For example, Swinburne (quoted by Watts 1998:171) says that he does not invoke God to explain fine-tuning, or what science cannot explain. He postulates God to explain what science can explain. The main motive in the dialogue is not to harmonise the different positions. If scientific claims can be regarded as consistent with theology, then it must be possible for scientific claims to be inconsistent with theology, according to Watts (1998:178). If this was not the case then everything in science must be consistent with everything in theology.

\section{EVOLUTIONARY BIOLOGY}

When it comes to humans and their cultural creations such as moral systems and religious positions, evolutionary biology seems to offer more than physics does. Living organisms (studies in evolutionary biology) seem to demand a more powerful pattern of explanation than that offered by the fundamental laws of physics. Evolutionary biology deals with the dynamic interaction between organisms and their environment. In physics and in chemistry phenomena are primarily classified in terms of what they do and in terms of their micro-structure, whereas in biology phenomena are primarily classified in terms of their purpose or function. Consequently, biology offers a greater variety of types of explanation, since what happens may be explained in functional terms; how it happens can be shown in causal terms, and why the organism is structured so that this behaviour can happen can be described in evolutionary terms (Drees 1996:18-19). From the side of cosmology, ecology and Christian spirituality, there has been general insistence over the last few years, that life needs to be approached in a holistic manner. Evolutionary biology indicates how tightly knit the relations are between organisms and their world. 


\section{THE DIALOGUE BETWEEN RELIGION AND EVOLUTIO- NARY BIOLOGY}

Drees (1996:196ff) distinguishes six positions in the debates on evolution and religion. The first three depict theological approaches to evolution and the last three scientific and evolutionary explanations of religion. They are:

- Creationism (conflict model): The debate is distinguished by a literal reading of the Bible. This approach sees the Bible and evolution as mutually exclusive.

- The design argument: This is a more open approach to evolution. The emphasis is on the idea that the natural order displays evidence of design. The design argument is also found in the Anthropic Principle, as applied in cosmology. As is the case with creationism, the options presented are mutually exclusive: either one accepts that order is the product of purposeful design or one accepts chance, since natural selection operates on variety due to random mutations.

- A mediatory approach: In this approach Christian beliefs are not considered to be necessarily inconsistent with the evolutionary origin of species. The question of God's action in the world is dealt with in different ways. Some see divine action hidden in what science calls chance; others see chance as chance also from God's side. Others again opt for God as the "Primary Cause" of the evolutionary process, the laws of nature and the required initial conditions, while holding the evolutionary account to be complete in itself, without requiring any special divine action within the realm of causality. Theological positions may be reconsidered and reformulated to defend the consistency of scientific knowledge and religious convictions.

The following three positions are distinguished in the evolutionary approach to religion and morality:

- The history and evolution of Christianity and other religions are discussed (by nineteenth century theologians like F C Baur, Albrecht Ritschl, Von Harnack and Troeltsch). 
- The significance of Christian faith for the evolutionary process is considered in a second approach. For example, the role of religious faith in the evolution of the human species is considered.

- A last approach formulates theological proposals which are relevant to us, and which are adequate with respect to our knowledge about the evolved character of the world, of morality and of religion.

\section{EVOLUTIONARY EPISTEMOLOGY}

Deliberations in evolutionary epistemology and its link with postmodernist sentiments seem to impact significantly on our understanding of knowledge. Evolutionary epistemology links human understanding with its biological roots and has implications for various disciplines, ranging from theology to psychology, sociology and of course epistemology.

Evolutionary epistemology is a byproduct of evolutionary biology and provides models for human self-understanding. It claims that the growth of knowledge is akin to the evolutionary growth of organisms. All knowledge is shaped and informed by certain innate principles which have influenced human thought because of their adaptive value. Recent studies on autopoietic systems seem to present fascinating examples of how knowledge and the human body are structurally related.

The main thesis of evolutionary epistemology is that human mental capacities result from organic evolution. Wuketits (quoted by Van Huyssteen 1998:137ff) considered the model of evolutionary epistemology to be a Copernican turn since it excluded the need for supernatural principles being imposed from "outside" on religious thinking. Thinking and knowledge could now be seen as part of the same biologically-based process.

Evolution itself is regarded as a cognitive process. The process of gaining knowledge is characteristic of all living beings, which means that human rationality too has a biological basis. This favours interdisciplinary reflection and holds the promise of a mutual ground for the science-religion dialogue (Van Huyssteen 1998:148-149). Wuketits (quoted by Van Huyssteen 1998:149) sees the processing of information as occurring on the genetic level (where information is transmitted by inheritance), on the 
preconscious level (where an information-processing system like the nervous system is a prerequisite) and on a conscious level (where rational knowledge is possible because of consciousness).

Van Huyssteen (1998:132) considers the theory of evolution by natural selection to be the most important link between religion and knowledge. The importance of this comes to the fore when it is realised that the gap between the physical and metaphysical, between mind and body, inner and outer world, naturalism and supernaturalism seems to be bridged. This becomes possible because of the mutual biological roots alleged to be operating in religion and knowledge. Human thinking and reasoning, human emotion including the spiritual sphere - all have their roots in biology.

For Van Huyssteen (1998:152), the importance of evolutionary epistemology lies in its ability to break the modernist subject-object polarisation, which emphasises that cognition is a function of active systems which interact with their environment. Cognition, from the perspective of evolutionary epistemology, is not an endless, accumulative chain of adaptations, but rather a complex interactive process in which we move beyond our biological roots without ever losing touch with them - perspectives which Van Huyssteen considers to be vital within a postfoundationalism epistemology. Natural evolution must be understood as a non-deterministic theory which acknowledges the importance of environmental interaction in the development of human cognition and culture.

\section{NATURAL SELECTION AND AUTOPOIETIC SYSTEMS}

Humberto Maturana and Francisco Valera introduced the model of autopoietic systems ${ }^{1}$ which proved to have far-reaching implications for ideas about the nervous system, perception, language and cognition in general. They introduced the concept of autopoietic systems to describe the nature of living as opposed to non-living systems and in

\footnotetext{
1 Autopoietic systems belong to the so-called third generation of systems theory. The first generation of systems theory is the classical system of antiquity which considered systems as harmonious wholes with well-adjusted parts. The second generation of systems theory is the modern systems theory which originated in the middle of this century and which emphasised the system-environment distinction. The third-generation systems theory of which autopoiesis and self-organisational systems are examples emphasises the importance of self-reference (Gregersen 1999:119-120).
} 
this way explained the nature of life. Their work is based upon some fundamental observations of living systems:

- Living entities have an individual autonomy. They belong to a species and group, and are affected by their environment, but remain self-defined entities.

- Living systems are essentially mechanistic. Their behaviour and development depend only on the properties and relations of their components and the interaction of neighbouring elements.

- All explanations are made by observers and one must not confuse what pertains to the observer with that which pertains to the observed. Observers can perceive both an entity and its environment and relate the two. Interacting living components cannot do this.

- Consequently, any explanation of living systems should be non-teleological, that is, it should not have recourse to ideas of function and purpose (Mingers 1989: 161).

These observations seem to support the stance of Drees (1996:xi), who appreciates the place and role of religion in our lives, but does not see religiously relevant gaps in the natural and human world where the divine could interfere with natural reality. However, autopoietic systems proved to be a useiul model to explain societal and religious systems.

The principle of autopoiesis is deduced from the operation of the cell which produces large numbers of complex chemicals which remain in the cell, but also participate in the actual production processes. The cell is an autopoietic system since it produces only itself. It differs from allopoietic systems which produce something other than themselves and also from heteropoietic systems which are produced by humans with a specific purpose in mind. Allopoietic systems do not define their own organisation, but depend on an observer to determine their identity. Autopoietic systems do not depend on any observer to perform their functions; they are autonomous and define themselves through the production of their own boundaries. An autopoietic system is thus a dynamic system that can be defined as a composite unity which is a network of production of 
components that, through their interaction, recursively regenerate the network of productions that produced them, and realise this network as a unity in space in which they exist by constituting and specifying its boundaries as surfaces of cleavage from the background through their preferential interactions within the network (Maturana, quoted by Mingers 1989:164). There is nothing in autopoietic systems that suggests that they cause particular structures to arise. There is no need for functionalist explanations or teleonomic ideas such as purpose, in the explanation of living things, although they may be useful in the descriptive language of an observer who does not only focus on components, but also on their unity and the history of their development (Mingers 1989:167). Even reproduction, heredity and evolution are secondary to the establishment of a single autopoietic entity. Although they do interact with their environment, the environment does not determine what will be the changes of the state of the system. Successful autopoiesis will lead to the selection, in the organism, of a structure which is suitable for its specific environment, although the environment does not specify the adaptive changes that will occur. Autopoietic systems behave purely in terms of their particular structure at a point in time and the neighbouring interaction of their components. The idea that DNA contains or transmits information or that the brain processes formal representations or symbols must be purely metaphorical and does not describe how such systems actually operate in themselves. Autopoiesis shows how systems can function in a decentralised, non-hierarchical way purely through the individual interactions of neighbouring components (Mingers 1989:168-170, 173).

\section{AUTOPOIESIS AND EPISTEMOLOGY}

The epistemological relevance of autopoiesis pertains to the role of the observer. The domain of description is inevitably relative to the describer. This means that we, as observers, can never escape from the domain of description and have access to an absolute, objective reality. This idea brings the discussion of the distinction between appearance and reality into focus again. It also underscores the likelihood that perceptions and cognition are evolutionary adaptations to the real world - an idea which originated with J L Austin in his Sense and Sensibilia (1962). 
If we accept that the observer is the constituter of his or her reality, that we are all observers with our own version of reality, and that reality is not something absolute which has been given to us from the outside, then the question arises: what do we need to observe in order to agree that understanding has occurred? We observe another human or animal from two different aspects. Firstly we observe the behaviour, which occurs in relation to its surrounding world and secondly we observe the body - its physiology.

Maturana has alerted us to the fact that behaviour and physiology are distinctly different domains which do not intersect. The word languaging can be used to depict our behaviour in our environment and emotioning to depict our physiological state or bodyhood. Languaging concerns our behaviour which is always relational since it concerns the organism's connection with the world in which it lives. Maturana saw languaging as a particular kind of behaviour, which is a second order of coordination, that is, it is the coordination of coordinations of behaviour. Languaging enables us to reflect and report on our experiences and provides the most obvious means of interacting with one another. This happens on a connotative level, rather than on a denotative level. In languaging we construct our own reality. In this virtual world in which we are immersed we structure our behaviour to make sense. Languaging is the act of reflecting on behaviour. Once we have reflected we are cognitively different - our physiological coherence has changed. Cells, organs or bodies do not choose - they simply live - but as languaging beings, we bring forth a higher-order self-reflection which becomes crucial for our existence (Fell \& Russell 1994:8).

Maturana saw emotioning as bodily predispositions to action and that certain characteristics of behaviour could be used to distinguish certain emotions (Fell \& Russell 1994:9). These emotions are described in metaphors which yield a coherent cognitive model about our bodyhood. Metaphor is used in this regard, not to represent an external reality, but to organise and describe our experience. Emotions like love, fear, domination, submission, anger and joy are displayed in our bodyhood and described metaphorically. Our feelings do not necessarily correspond with our emotioning, since feelings are a commentary about our experience, shaped in languaging. It is rather in lived experience that we come to understanding. Through the converging of languaging and emotioning, semantic connection becomes possible, which, through conversation, 
results in cognition. It is not our rationality which distinguishes us from animals, but the way in which our rationality and emotions are braided together (Fell \& Russell 1994:12).

The linking of languaging with emotioning helps us to overcome the mind-body dualism. Knowledge has bodily roots, and is linked to our bodyhood, while rationality is bound to our experiences.

\section{METAPHORICAL APPLICATIONS OF AUTOPOIESIS ON A SOCIETAL LEVEL}

The autopoietic system has fascinating metaphorical applications. Humans can be seen as autopoietic entities and, as such, are autonomous and independent. Human societies can be seen as biological systems because:

- they survive;

- their methods of survival answer the autopoietic criteria, and

- the system may well change its entire appearance and its apparent purpose in the process (Mingers 1989:172).

Niklas Luhman has written extensively on the implications of autopoietic systems for society. He sees social systems as self-referential systems based on meaningful communication. They use communication to constitute and interconnect the events (actions) which build up the system and can thus be regarded as autopoietic systems. Social systems exist only by reproducing the events which serve as components of the system. They consist of events and actions which they themselves produce and they exist only as long as this is possible. The environment of social systems includes other social systems. The political system includes, for example, the economic and medical systems and so on. Societies make communication between other social systems possible, although society itself cannot communicate (Luhman 1982:131).

Sociocultural evolution began with segmentary systems. All traditional societies that produced enough complexity for high culture were stratified societies, hierarchically structured. Modern society, however, uses function and not hierarchy for the differentiation of subsystems. Modern society is into the political subsystem and its environment, 
the economic, scientific, educational, religious subsystems and their environments. These subsystems with their communicative networks have become global systems. A self-referential system defines itself by the way in which it constitutes its elements and thereby maintains its boundaries. In systems theory, the distinction between system and environment replaces the traditional emphasis on the identity of guiding principles or values. Differences, not identities, provide the possibility of perceiving and processing information. The social system can change its own structures only by evolution. Evolution presupposes self-referential reproduction and changes the structural condition of reproduction by differentiating mechanisms for variation, selection and stabilisation. Society, however, cannot plan itself - just as evolution cannot plan itself. But a selfreferential system which tries to absorb planning may speed up its own evolution, because it becomes hyper complex and will force itself to react to the ways in which it copes with its own complexity (Luhman 1982:132-135). The emphasis thus falls on difference, not identity, autonomy and not control, relation and not ontology, dynamism and not stability, evolution and not planning. These have become the traits of present day postmodern societies.

\section{THE PLACE OF GOD IN THE AUTOPOIETIC MODEL}

Gregersen has attempted to show how the action of God can be seen in autopoietic systems. Gregersen (1994:25ff) recognises that religious and biological conceptions of life differ and so also the way each discipline reads, describes and redescribes reality. Although theology and biology are both rational disciplines, their specific focus and aim differ so radically that their language, metaphors, and style of reasoning cannot be compared. The point, however, is that the challenges put to theology from the side of the natural sciences force theology to interact with the sciences by taking up their language, models and theories and by redescribing the theological interpretation of reality in this light. This is not to say that the theological language of apologetics becomes the standard language of religion, although it influences it. Utterances on this level are termed "theology 2" by Gregersen (1999:122) in distinction to "theology 1", which is the language of faith. For Gregersen Christian faith should not prematurely be translated into the philosophical or scientific language of an abstract "theology 2". 
On an existential level in everyday life we combine religious and scientific metaphors to make sense of our situation. Scientific and religious metaphors do not compete on this level, but are an integral part of our reasoning, even though these metaphors may not always be compatible. The present multiplicity of scientific and religious metaphors and models for describing reality were not part of the worldview of biblical times, which made it easier for biblical writers to display a harmonious picture of the world.

Gregersen (1998:133) finds it possible to be simultaneously an evolutionist and a believer in God, to hold onto creation faith and to evolution. God is not just somehow "behind" life-processes, God is "present" in them. God is not only the pre-moral initiator of a premoral world, God is also the moral inspirer of sentient beings, like humans and higher mammals (pp 130,138). His main thesis is that God creates and transforms the world through supporting and stimulating self-making systems (p 354). God is a triggering cause, who is switching in and out in order to hold the course of history on track. God does not, however, do anything that replaces the ordinary operations of nature. God is the underlying causality that enables creatures to trigger themselves forth in their given setting (1998:358-359). Gregersen uses the Genesis concept of God's blessing as metaphor for the way God allows binary relations between Creator and creature and multi-lateral relations between creatures in the horizontal nexus of time, conjoining life processes and cultural processes. God's blessing gives creatures the power to reproduce themselves abundantly. This blessing is not only bestowed upon the individual creatures but also on the working inside of them - accommodating the principle of autopoietic systems. God is continuously upholding the reproductive and self-productive capacities of matter from the simplest to the most complex forms. As Creator of the self-evolving world then, God is continuously acting amorally or premorally (since randomisations occur with no distinction between good and evil), but God is not acting immorally, that is with an evil intent (autopoietic theodicy?) (Gregersen 1998:348, 351ff, 355). Gregersen (1998:356-357) interprets God's incarnation to include God's intimate knowledge of the (biological) particulars of the actual world. God is the compassionate co-sufferer of the trials and errors, accomplishments and breakdowns of creatures. In this sense God supports and stimulates creatures, who, on their side, are co- 
exploring the joys and risks of God's creation. It is not clear what the place of these risks are when it comes to issues like suffering, evil and death. Gregersen (1999:133) sees no way of dealing theologically with the problem of animal pain and human evil, other than by acknowledging that God's creation remains unfinished business. From a biological point of view pain, suffering and death are seen as unavoidable and natural features (Gregersen 1994:142ff; Peacocke: 1990:63, 68).

Gregersen (1998:361) sees God as constantly shaping and remoulding the possibility spaces of autopoietic systems and believes that his structuring model of divine action has specific advantages:

- the model articulates a divine influence on the processes of nature that transcends the popular idea that God acts only by creating the world system as a whole;

- it articulates God's infinite capacity for self-relativisation as shown in the incarnation; and

- it links the idea of God's blessing with God's interaction with human beings.

What we thus have is a radically temporalised and localised form of divine interaction with self-organising systems (Gregersen 1999:128).

The autopoietic system poses radical questions to ethics and human responsibility. This concerns the place of human ethics in autopoietic systems. One has to keep in mind what Luhman said concerning present day societies and the fact that societies (ethical systems) cannot be planned. On an ethical level, Gregersen (1994:146) believes that the religious view of life must be able to integrate the process of natural selection as a basic condition established by God and it must, as a culture-bearing spiritual power, be able to influence the form of the process of natural selection. The idea of an evolutionary understanding of morality, or religion for that matter, seems to undermine the very concept of morality or religion.

Van Huyssteen refers to the ethical impact of evolutionary epistemology and gives it a cognitive slant. Van Huyssteen (1998:140) sees the everyday choices we make as a paradigm for rationality in action, as an example of how we intelligently cope with the world. The evolutionary model favours, as in postmodernism, a multiplicity of expla- 
natory models, views and interpretations of our interaction with the world. Does this favour ethical pluralism and relativism? The same question may be asked in connection with the world of religions, where the claim to one exclusive true religion does not hold anymore.

Drees (1996:204-205) feels that it is a natural enterprise to understand our constitution and behaviour in analogy with other species. Although he acknowledges the biological roots of human ethics, he feels that the influence of culture and cognitive capacities, and the behavioural plasticity thus generated, cannot be over-estimated. We cannot link human ethics in a deterministic manner to our genetic heritage, although its important influence cannot be ignored (it must be remembered that freedom stands over against determinism and that freedom is self-determination). With reference to the work of Alexander, Drees (1996:207-208) concludes that the evolution of cultures with moral codes has been driven by two factors: group cohesion (for the group as a whole, against other groups) and indirect reciprocity (as a mechanism serving individual interests within a group). Acknowledging the evolutionary influence in ethics implies accepting human selfishness - which may not be easy in a culture praising altruism. The evolutionary perspective on ethics brings into focus that our moral language and ethical principles can be seen as a screen for hiding amoral motives.

If human genetic information must be joined with non-genetic, cultural information, which is transformed by language and example, the question arises to what extent this is also valid for the phenomenon of religion? It would also be difficult to ascertain the exact ratio between genetic influences on the one side and cultural, cognitive or other influences on the other. Through ritual and story, religions mediate between the genetic and cultural level as they transfer cultural information to the brain, the steering mechanism of individuals. Drees (1996:212-213) states three general claims about religion in an evolutionary perspective: Firstly, humans, their cultures, languages, aesthetic and moral codes, and their religious practices, are seen as a result of a natural, evolutionary process; secondly the actual history of morality and religions and their actual functioning in the web of genes, mind, and culture are very complex and not clear; and thirdly, religion must be seen as having contributed significantly to the evolutionary process. Along the same lines Wuketits (quoted by Van Huyssteen 1998:146-147, 157) does not attribute the complex patterns of human culture (and religion) to the exclusive 
result of the principle of organic evolution, since it exhibits its own characteristics and system conditions. Cultural evolution requires explanations beyond the biological theory of evolution. Cultural evolution depends upon specific biological processes, but once started it obeyed its own principles and human evolution started an entirely new direction, even acting back upon organic evolution.

\section{THE PROBLEM OF CIRCULAR REASONING AND THE USE OF ANALOGY AND METAPHOR}

Gregersen (1999:129) acknowledges some degree of circular reasoning when using biological theories as a hermeneutical guide for constructing theism and theism as a hermeneutical guide for interpreting biological theories. He sees this, however, as part of any hermeneutical endeavour and as a part of a pragmatic coherentist ${ }^{2}$ epistemology, like that of Rescher, which he makes use of. Gregersen's style of reasoning is similar to most of the positions one finds in the science-religion dialogue. Whether we find a causal joint for God's action in the field of quantum physics, in the kenosis model, in the Anthropic Principle or in autopoietic systems, there remains a circular way of reasoning when biblical ideas and those of natural science are related to each other. We have distinct sets of metaphors used in science and in religion. Different disciplines generate different metaphors. Metaphoric "openings" in science provide opportunity for religious intervention and vice versa. New metaphors may be invented or science metaphors may be "borrowed" by theology and extended for theological purposes. This makes theology subservient to non-theological metaphors on the one hand, but prevents it from becoming irrelevant, on the other.

We cannot escape the analogical and metaphoric nature of our reasoning ${ }^{3}$ (see McGrath 1998:179ff; McGrath 1999:144-174). Metaphors give "epistemic access" to the world. The world informs our theories, even though our theories never adequately

2. Whereas empiricism works by way of inductive reasoning, coherentism starts out in a larger set of holistic theories in order to rule out more inefficient theories in favour of more workable theories (Gregersen 1999:129).

3. As an example of the use of analogy in the natural sciences, it is interesting to note that Darwin got the concept of "natural selection" from the methods of livestock breeders and pigeon-fanciers, who used artificial selection as a means of generating and preserving desirable characteristics within the animal world. He then developed the term as a metaphorical and non-literal way of referring to a process which he believed explained the patterns of diversity he observed in nature (Ruse 1986:35; McGrath 1999:157ff). 
describe the world. Metaphors allow us to depict reality without being naively and unrevisably descriptive (Duce 1998:118-119).

Whereas models and metaphors in science may be seen as useful fictions requiring no personal commitment or as symbolic representations for particular purposes, they are seen in theology "to be given" and are taken up in a more serious way like the metaphor of God as father and shepherd. We live religiously in metaphors, while they may be regarded as dispensable scaffolding in science circles.

In using analogy one may try to show that, despite differences, in crucial relevant ways things being compared are identical. Ruse (1986:34) speaks of analogy-as-justification in this regard. As an example we can take the analogy between the development of evolution or organisms and the supposed development or evolution of scientific knowledge. Herbert Spencer (1857) argued that we see everywhere a "law or progress", which takes the form of complexity arising from simplicity or from heterogeneity arising from homogeneity. It happens in science (culture) as it happens in nature. We know, however, that organic evolution is not progressive and that, although science seems to be progressive, not all scientific change is progressive. Most scientific theories, including those for which the greatest claims have been made, have come crashing down (Ruse 1986:49). The progressiveness of science cannot be found in the formulation of final unchangeable truths. Kuhn has indicated that scientific revolutions move through radical epistemic breaks.

\section{POSTMODERNISM AND EVOLUTION}

Postmodern ideas seem to be congruent with the findings of evolutionary biology. The idea of randomness can be compared to the Derridean idea of difference. Many other ideas of evolutionary biology that fit in with postmodernist sentiments can be mentioned: the idea that complexity creates new complexity; the ideas of holism and interconnectedness; self-preserving and self-generating systems; the denial that we can speak of progress in evolution; the mind-body unity; openness and self-reference; the influence of the environment, the role of the observer and the fact that meaning is related to the observer. Van Huyssteen (1998) has dealt with the importance of postmodern ideas for postfoundationalism and the role evolutionary biology plays in this. 
The question is to what extent these ideas will filter through to the existential level of religious experience. The church was for may years the custodian of truth and had a monopoly on knowledge, determined the world-view linked to this knowledge and prescribed the ensuing life style, ethics and value systems. The church claimed its knowledge to be revealed by God in the Bible as God's special revelation. Religions, today, are challenged to bring their belief system in line with the present day world-view. Theology must redescribe its world-view in the rationality proper to religion. This can only be done meaningfully by utilising the existing metaphors developed by, for example, evolutionary biology and applying these analogically to the world of faith. Theology, like all other epistemological activities, is highly selective. Theology is relative to its environment, but it is inner-theological criteria that determine which of the inputs coming from that environment will be allowed to influence that theology (Gregersen 1994:126). Although inner-theological criteria are changing and often diverse, we do experience in the science-religion debate an earnest effort to critically grapple with the challenges. One can only welcome this.

\section{Works consulted}

Appleyard, B 1992. Understanding the present. London: Picador.

Drees, W B 1996. Religion, science and naturalism. New York: Cambridge University Press.

Duce, P 1998. Reading the mind of God. Apollos: Leicester.

Fell, L \& Russell, D 1994. Towards a biological explanation of human understanding. Cybernetics \& Human Knowing 2(4), 3-15.

Gregersen, N H 1994. Theology in a Neo-Darwinian world. Studia Theologica 48(2), 125-149.

- 1998. The idea of creation and the theory of autopoietic processes. Zygon 33(3), 333368.

- 1999. Autopoiesis: Less than self-constitution, more than self-organisation. Reply to Gilkey, McClelland, Delete, and Brun. Zygon 34(1), 117-138.

Gregersen, N H \& Van Huyssteen J W (eds) 1998. Rethinking theology and science. Grand Rapids: Eerdmans. 
Luhman, N 1982. The world as society and as a social system. International Journal of General Systems 8, 131-138.

McGrath, A E 1998. The foundations of dialogue in science \& religion. Oxford: Blackwell.

- 1999. Religion and science. Oxford: Blackwell.

Mingers, J 1989. An introduction to Autopoiesis: Implication and applications. Systems Practice 2(2), 159-180.

Peacocke, A 1990. Theology for a scientific age. Oxford: Blackwell.

Ruse, M 1986. Taking Darwin seriously. Oxford: Blackwell.

Thiselton, A C 1995. Interpreting God and the postmodern self. Edinburgh: T \& T Clark.

Van Huyssteen, W J 1998. Duet or duel? Theology and science in a postmodern world. London: SCM.

Watts, F 1998. Science and theology as complementary perspectives, in Gregersen, N H \& Van Huyssteen, J W (eds), Rethinking theology and science, 157-180. Grand Rapids: Eerdmans. 